\title{
Heating effects on physicochemical characteristics and antioxidant activity of flaxseed hull oil (Linum usitatissimum L)
}

\author{
Wahid HERCHI ${ }^{1,2 *}$, Kamel BEN AMMAR ${ }^{3}$, Intidhar BOUALI², Ikram BOU ABDALLAH², \\ Arbi GUETET ${ }^{4}$, Sadok BOUKHCHINA ${ }^{2}$
}

\begin{abstract}
The aim of this study was to analyze the effects of heating on some quality characteristics and antioxidant activity of flaxseed hull oil. Polyunsaturated fatty acids (PUFA) and Cox value decreased during heating. Heating process led to considerable increase in saponification value (SV), peroxide value (PV), $p$-anisidine value $(p-A n V)$, oxidative value $(\mathrm{OV})$ and specific extinction at 232 and $270 \mathrm{~nm}$. There was a significant decrease in oil stability during heating process $(1.4-1.0 \mathrm{~h}$ ). Fuel properties of flaxseed hull oil were also changed after heating treatment. Heating process caused loss of total phenolic acids, total flavanoids, carotenoids and chlorophyll pigments. Phospholipids (PL) content were less changed compared to other bioactive compounds. Antioxidant activity of flaxseed hull oil decreased during heating process.
\end{abstract}

Keywords: antioxidant activity; flaxseed; heating; hull; oil.

Practical Application: The above study regards the possibility of knowing the heating effects on the chemical composition of flaxseed hull oil produced in Tunisia from autochthonous variety. Vegetable oils are one of the main constituents of the diet used for cooking purposes. Valuable information will be provided for flaxseed hull breeders and growers in developing and producing functional food resources and products.

\section{Introduction}

Flaxseed hulls are low valued by-product obtained after flaxseed dehulling process. It represents $22-36 \%$ of the total flaxseed weight, depending on the dehulling technology utilized (Oomah \& Sitter, 2009). Flaxseed hulls contain approximately $25 \%$ of protein (Gagnon et al., 2009) and $15-30 \%$ of oil with around $45 \%$ of mono and polyunsaturated fatty acids (PUFA), especially $\omega$-3 fatty acids (Oomah \& Sitter, 2009). Moreover, flaxseed hull is a source of carbohydrates and phenolic compounds (Herchi et al., 2014). The main carbohydrates are hemicellulose and cellulose, while the main phenolic compounds are ferulic, chlorogenic, gallic and 4-hydroxibenzoic acids (Oomah \& Sitter, 2009). Flaxseed hulls are a rich source of soluble and insoluble (dietary) fiber, and contain a very high concentration of the lignan, secoisolariciresinol diglycoside (SDG), which exhibit a high antioxidant activity making the hulls an attractive functional ingredient (Hao \& Beta, 2012). Different physical and chemical parameters of vegetable oils were used to monitor the compositional quality of oils (Herchi et al., 2015). These physicochemical parameters include iodine value (IV), saponification value (SV), density, peroxide value (PV) and antioxidant activity.

Vegetable oils are one of the main constituents of the diet used for cooking purposes. Several researchers studied the impact of temperature on the stability, density, peroxide value, and iodine value to assess the quality and functionality of the oil (Erum et al., 2014). Some scientists have studied the physicochemical characteristics and fatty acid composition of flaxseed hull oil. The physicochemical characteristics of flaxseed hull oil at maturity were as follows: iodine number $\sim 170$, saponification value $\sim 178$ and peroxide value $\sim 1.80$ (Herchi et al., 2014). The major fatty acid found in flaxseed hull oil was linolenic acid (49\%) (Herchi et al., 2014). Saturated fatty acids ranging between $11 \%$ and $12 \%$ (Herchi et al., 2014). In a previous paper, we reported that the antioxidant activity of flaxseed hull oil was 70\% (Herchi et al., 2014). Although flaxseed hull composition has been studied (Oomah \& Sitter, 2009; Herchi et al., 2014, 2015). However, no information is available concerning the effect of heating process on physicochemical characteristics and antioxidant activity of flaxseed hull oil.

Therefore, the main objective of this study was to study, for the first time, the heating effect on quality and stability characteristics of flaxseed hull oil to increase its value and contribution to the development of new omega-3 products for the functional foods and nutraceutical applications.

\section{Materials and methods}

\subsection{Chemicals and reagents}

All solvents and standards used in the experiments were purchased from Fisher Scientific Company (Ottawa, Ontario, Canada). 


\subsection{Plant material}

Flaxseed Hull (C17) was obtained from Institut National Recherche Agronomie Tunis (INRAT), Tunisia. The dehulled seed and hulls were separated by air aspiration.

\subsection{Oil extraction}

The total lipids were extracted by the method of Folch et al. (1957) modified by Bligh \& Dyer (1959). Flaxseed hull (200 g) were washed with boiling water for $5 \mathrm{~min}$ to denature the phospholipases (Douce, 1964) and then crushed in a mortar with a mixture of $\mathrm{CHCl}_{3}-\mathrm{MeOH}(2: 1, \mathrm{v} / \mathrm{v})$. Fixing water was added and the homogenate was centrifuged at $3000 \mathrm{rpm}$ for $15 \mathrm{~min}$. The lower chloroformic phase containing the total lipids was dried in a rotary evaporator at $40{ }^{\circ} \mathrm{C}$.

\subsection{Heat process}

Heat process was done using a domestic electronic heater plate with an intelligent magnetic stirrer and the sample were heated at $110^{\circ} \mathrm{C}$ for $12 \mathrm{~h}$. Unheated sample was used as control (corresponding to $0 \mathrm{~h}$ ). After heating process, flaxseed hull oil were drained under a stream of nitrogen and then stored in a freezer $\left(-20^{\circ} \mathrm{C}\right)$ for subsequent analyses.

\subsection{Gas Chromatography-flame Ionization Detection (GC-FID)}

The quantification of fatty acids methyl esters was performed using a gas chromatography - flame ionization detection (GC-FID) apparatus. Fatty acid methyl esters were prepared by simultaneous extraction and methylation following the procedure described by Metcalfe et al. (1966) modified by Lechvallier (1966). Methyl esters were analyzed by GC, using an HP 4890 gas chromatograph equipped with a FID detector on a capillary column coated with Supelco wax TM 10 (30 m long $\times 0.25 \mathrm{~mm}$ i.d., and $0.2 \mu \mathrm{m}$ film thickness), a split/splitless capillary (1:10) injector. Helium was used as the carrier gas at a flow rate of $1 \mathrm{ml} / \mathrm{min}$. Temperatures of the column, detector, and injector were 200,250 , and $230{ }^{\circ} \mathrm{C}$, respectively. The identification of the peaks was achieved by retention times by means of comparing them with standards analyzed under the same conditions. The area under each peak was measured and the percentage expressed in regard to the total area. The Cox value of the oil was calculated based on the percentage of unsaturated $\mathrm{C} 18$ fatty acids, applying the formula proposed by Fatemi \& Hammond (1980) (Equation 1):

Cox value $=[1(18: 1 \%)+10.3(18: 2 \%)+21.6(18: 3 \%)] / 100$

\subsection{Physicochemical characteristics}

Determination of Density, Saponification value (SV), Acid value (AV), Free fatty acids (FFA), Iodine value (IV), $p$-anisidine value ( $p$-AnV), Peroxide value (PV), UV absorption characteristics $\left(\mathrm{K}_{232}\right.$ and $\left.\mathrm{K}_{270}\right)$, and unsaponifiable matter (UM) of the extracted oil was carried out by standard IUPAC methods for the analysis of fats and oils (Dieffenbacher \& Pocklington, 1987). Oxidation value $(\mathrm{OV})$ was calculated from Holm's equation, $\mathrm{OV}=p-\mathrm{AnV}$ $+2(\mathrm{PV})$, while theoretical flavor scores (F) were obtained from equation $\mathrm{F}=7.7-0.35$ (OV) (List et al., 1974). Oxidative stability was evaluated by the Rancimat method (Gutierrez, 1989). Stability was expressed as the oxidation induction time (hours), measured with the Rancimat 743 apparatus (Metrohm Co., Basel, Switzerland), using an oil sample of $3 \mathrm{~g}$ warmed to $100{ }^{\circ} \mathrm{C}$ and air flow of $10 \mathrm{l} / \mathrm{h}$. Higher Heating Value (HHV), known as the gross calorific value or gross energy, represents the heat released by the oxidation of a fuel in air. The HHV is the amount of heat produced by the complete combustion of a unit quantity of fuel. The HHV of flaxseed hull oil was calculated from the density (d); the iodine value (IV) and saponification value (SV) derived using the following formula adopted by Demirbas (1998, 2000) (Equation 2, 3 and 4).

$$
\begin{aligned}
& H H V=49.43-(0.041 \times S V)-(0.015 \times I V) \\
& H H V=79.014-43.126 d \\
& H H V=-45.736+224.028 d-142.935 d^{2}
\end{aligned}
$$

The cetane number of the oil was determined according to Bose (2009) (Equation 5):

$C N=46.3+5458 / S V-0.225 \times I V$

\subsection{Thin-layer chromatography}

Unsaponifiable lipids were determined by saponifying $5 \mathrm{~g}$ of lipid extracts with $50 \mathrm{~mL}$ ethanolic $\mathrm{KOH} \mathrm{12 \%} \mathrm{(w/v)} \mathrm{heating}$ at $60{ }^{\circ} \mathrm{C}$ for $1.30 \mathrm{~h}$. After cooling, $50 \mathrm{~mL}$ of $\mathrm{H}_{2} \mathrm{O}$ was added and the unsaponifiable matter was extracted four times with $50 \mathrm{~mL}$ petroleum ether. The combined ether extract was washed with $50 \mathrm{~mL}$ of $\mathrm{EtOH}-\mathrm{H}_{2} \mathrm{O}$ (1:1). The ether extracted was dried over anhydrous $\mathrm{Na}_{2} \mathrm{SO}_{4}$ and evaporated. The dry residues were dissolved in chloroform for TLC analysis. The unsaponifiable matter was separated into subfractions on preparative silica gel thin-layer plates (silica gel 60 G F254), using 1-dimensional TLC with hexane- $\mathrm{Et}_{2} \mathrm{O}$ (65:35 by volume) as the developing solvent. The unsaponifiable ( $4 \mathrm{mg}$ in $100 \mu \mathrm{L} \mathrm{CHCl}_{3}$ ) was applied on the silica gel plates in $3 \mathrm{~cm}$ bands. After development the plate was sprayed with 20, 70-dichlorofluorescein and viewed under UV light. The identification of unsaponifiable classes was made by comparing their Retention Factor (RF) values with those of authentic standards chromatographed under the same conditions. The bands corresponding to unsaponifiable constituents were scraped off separately and each fraction was extracted three times with $\mathrm{CHCl}_{3}-\mathrm{Et}_{2} \mathrm{O}(1: 1)$, filtered to remove the residual silica, dried in a rotary evaporator and the dry residue was weighted.

\subsection{Total chlorophyll and carotenoids}

A $1.5 \mathrm{~g}$ sample of flaxseed hull oil was fully dissolved in $5 \mathrm{~mL}$ cyclohexane. Chlorophyll and carotenoid were determined colorimetrically following the method of Minguez-Mosquera et al. (1991). The maximum absorption at $670 \mathrm{~nm}$ is related to the chlorophyll fraction and at $470 \mathrm{~nm}$ is related to carotenoid fraction. The values of the coefficients of specific extinction applied were $\mathrm{E}_{0}=613$ for the pheophytin as a major component in the chlorophyll fraction and $\mathrm{E}_{0}=2,000$ for lutein as a major component in the carotenoid fraction. Thus the pigment contents were calculated as follows (Equation 6 and 7): 


$$
\begin{aligned}
& \text { Chlorophyll }(\mathrm{mg} / \mathrm{kg})=\left(A_{670} \times 10^{6}\right) /(613 \times 100 \times d) \\
& \text { Carotenoid }(\mathrm{mg} / \mathrm{kg})=\left(A_{470} \times 10^{6}\right) /(2,000 \times 100 \times d)
\end{aligned}
$$

where $\mathrm{A}$ is the absorbance and $\mathrm{d}$ is the spectrophotometer cell thickness $(1 \mathrm{~cm})$. The data reported is based on oil weight (mg/kg flaxseed hull oil).

\subsection{Polyphenols contents}

Extraction and determination of total phenolic acids and flavanoids contents were carried out according to the method of Gutfinger (1981).

\subsection{Determination of antioxidant activity}

The hull oil obtained was subjected to screening for its possible antioxidant activity. The oil was assessed using 1, 1-diphenyl-2picrylhydrazyl (DPPH) radical-scavenging assay. All the data were the averages of triplicate determinations of three tests. The DPPH free radical-scavenging activity of oil was measured using the method described by Gorinstein et al. (2004). A $0.1 \mathrm{mM}$ solution of DPPH in methanol was prepared. An aliquot of $0.2 \mathrm{~mL}$ of sample was added to $2.8 \mathrm{~mL}$ of this solution and kept in the dark for $30 \mathrm{~min}$. The absorbance was immediately measured at $517 \mathrm{~nm}$. The ability to scavenge the DPPH radical was calculated with the following equation (Equation 8):

Inhibition percentage $=(I \%)=\left[\left(A_{0}-A_{1}\right) / A_{0}\right] \times 100$

where $A_{0}$ is the absorbance of the control, $A_{1}$ is the absorbance in the presence of sample.

\subsection{Phospholipids (PL) content}

The SPE cartridge was preconditioned with $20 \mathrm{~mL}$ chloroform, $20 \mathrm{~mL}$ chloroform/methanol (9:1, v/v), and $20 \mathrm{~mL}$ chloroform. Lipid extracts dissolved in $2 \mathrm{~mL}$ chloroform were loaded onto the cartridge and eluted with the following solvents: $30 \mathrm{~mL}$ chloroform to remove neutral lipids, $25 \mathrm{~mL}$ acetone to remove glycolipids, and $30 \mathrm{~mL}$ methanol plus $10 \mathrm{~mL}$ of chloroform/methanol $(1: 1 \mathrm{v} / \mathrm{v})$ to recover phospholipids (PL). The recovered fraction was dried in a rotary evaporator and weighted in order to determine the PL amount in the oil.

\subsection{Statistical analysis}

Statistical analysis was performed by using the Proc ANOVA in SAS (software version 8). All analyses were replicated three times for each sample.

\section{Results and discussion}

\subsection{Changes in major fatty acids composition during flaxseed hull oil heating}

Table 1 shows the effect of heating on the average fatty acid composition of flaxseed hull oil. Linolenic fatty acid was always the major fatty acid found: its relative percentage was 47.19.
These results are in agreement with those previously reported (Herchi et al., 2014, 2015). The heating process caused a decrease in the relative percentages of the unsaturated fatty acids (Table 1). The decrease in PUFA in flaxseed hull oil was lower (55.46\%). Choo et al. (2007) reported that there was a significant decrease in linolenic acid resulting in a concomitant relative increase in palmitic, stearic, oleic and linoleic acids in the oils after pan heating. The data revealed that heating process caused a decrease in the $\Sigma \mathrm{TU} / \Sigma \mathrm{SFA}$ ratio. Cox values were statistically the same during heating of flaxseed hull oil. The calculated oxidizability (Cox) value which is based on unsaturated fatty acid percentages present in the oils, is a beneficial element usually taken as an evaluation of the oil's tendency to undergo autoxidation (Fatemi \& Hammond, 1980). The Cox value results demonstrated that flaxseed hull oil is almost stable and it could be used for protection of vegetable oils against oxidative deterioration.

\subsection{Changes in physicochemical characteristics and fuel properties during flaxseed hull oil heating}

Changes in physicochemical characteristics and fuel properties during heating of flaxseed hull oil are shown in Table 2. The increase in FFA (0.9-1.7) could be attributed to oxidation and hydrolysis that produces FFA. The tabulated data revealed that heating of flaxseed hull oil caused an increase in the acid value (1.5-2.9 $\mathrm{mg} \mathrm{KOH} \mathrm{g}^{-1}$ oil). According to the Codex Alimentarius Commission standard (Codex Alimentarius Commission, 2006), the acid value of the heated flaxseed hull oil was still within the limits for virgin oils and cold pressed fats and oils. These results indicate that heating of flaxseed hull oil at $110{ }^{\circ} \mathrm{C}$ does not cause much formation of free fatty acids due to oxidation or heat induced hydrolysis. The increase in the PV (1.85-5.2 mequiv $\mathrm{O}_{2} / \mathrm{kg}$ oil) indicates that this oil was unstable to oxidative degradation. Choo et al. (2007) reported that there were increases in $\mathrm{PV}$ and $p$-AnV of flaxseed oil during pan-heating. According to the Codex Alimentarius Commission

Table 1. Changes in Major fatty acids composition (\% GC area, mean of three measurements) during heating of flaxseed hull oil.

\begin{tabular}{lcc}
\hline $\begin{array}{c}\text { Fatty acid content } \\
(\%)\end{array}$ & Control & $\begin{array}{c}\text { Heated flaxseed hull } \\
\text { oil }\end{array}$ \\
\hline Fatty acids & & \\
C16:0 & $7.21 \pm 0.02^{\mathrm{a}}$ & $7.98 \pm 0.06^{\mathrm{a}}$ \\
$\mathrm{C} 18: 0$ & $4.16 \pm 0.10^{\mathrm{a}}$ & $4.59 \pm 0.14^{\mathrm{a}}$ \\
$\mathrm{C} 18: 1$ & $26.33 \pm 0.15^{\mathrm{a}}$ & $30.28 \pm 0.21^{\mathrm{b}}$ \\
$\mathrm{C} 18: 2 \mathrm{n}-6$ & $13.72 \pm 0.16^{\mathrm{a}}$ & $11.52 \pm 0.18^{\mathrm{b}}$ \\
$\mathrm{C} 18: 3 \mathrm{n}-3$ & $47.19 \pm 0.41^{\mathrm{a}}$ & $43.94 \pm 0.30^{\mathrm{b}}$ \\
Fatty acids groups & & \\
$\Sigma$ SFA & $11.37 \pm 0.12^{\mathrm{a}}$ & $12.57 \pm 0.20^{\mathrm{a}}$ \\
$\Sigma$ MUFA & $26.33 \pm 0.15^{\mathrm{a}}$ & $30.28 \pm 0.21^{\mathrm{b}}$ \\
$\Sigma \mathrm{PUFA}$ & $60.91 \pm 0.57^{\mathrm{a}}$ & $55.46 \pm 0.48^{\mathrm{b}}$ \\
$\Sigma \mathrm{TU}$ & $87.24 \pm 0.72^{\mathrm{a}}$ & $85.74 \pm 0.69^{\mathrm{b}}$ \\
$\Sigma$ TU/ $\Sigma$ SFA & $7.67 \pm 0.32^{\mathrm{a}}$ & $6.82 \pm 0.26^{\mathrm{b}}$ \\
Cox value & $11.87 \pm 0.20^{\mathrm{a}}$ & $10.98 \pm 0.16^{\mathrm{b}}$ \\
\hline SFA: saturated fatty acids; MUFA: monounsaturated fatty acids; PUFA: polyunsaturated \\
fatty acids; $\Sigma$ TU/ $\Sigma$ SFA: unsaturated fatty acids to saturated fatty acids ratio. Values given \\
are the means of three replicates \pm standard deviation. Means with different letters (a-c) \\
within a row are significantly different at $(p \leq 0.05)$.
\end{tabular}


Table 2. Changes in Physicochemical characteristics and Fuel properties during heating of flaxseed hull oil.

\begin{tabular}{|c|c|c|}
\hline Properties & Control & $\begin{array}{c}\text { Heated flaxseed } \\
\text { hull oil }\end{array}$ \\
\hline Average molecular weight ${ }^{\star}(\mathrm{g} / \mathrm{mol})$ & $935 \pm 3.22^{\mathrm{a}}$ & $905 \pm 2.84^{\mathrm{b}}$ \\
\hline Acid value (mg KOH g-1 oil) & $1.5 \pm 0.14^{\mathrm{a}}$ & $2.9 \pm 0.25^{\mathrm{b}}$ \\
\hline FFA content ( $\%$ as oleic acid) & $0.9 \pm 0.06^{\mathrm{a}}$ & $1.7 \pm 0.10^{\mathrm{a}}$ \\
\hline Peroxide value (mequiv $\mathrm{O}_{2} / \mathrm{kg}$ oil) & $1.85 \pm 0.08^{\mathrm{a}}$ & $5.2 \pm 0.15^{\mathrm{b}}$ \\
\hline$p$-Anisidine value & $1.10 \pm 0.17^{\mathrm{a}}$ & $8.50 \pm 0.32^{\mathrm{b}}$ \\
\hline Oxidation value & $4.8 \pm 0.16^{\mathrm{a}}$ & $11.90 \pm 0.24^{\mathrm{b}}$ \\
\hline Theoretical flavor scores (F) & $6.02 \pm 0.14^{\mathrm{a}}$ & $3.53 \pm 0.10^{\mathrm{b}}$ \\
\hline $\mathrm{K}_{232}$ & $1.50 \pm 0.10^{\mathrm{a}}$ & $2.35 \pm 0.12^{\mathrm{b}}$ \\
\hline $\mathrm{K}_{270}$ & $0.24 \pm 0.06^{\mathrm{a}}$ & $0.30 \pm 0.08^{\mathrm{b}}$ \\
\hline Oil Stability (h) & $1.4 \pm 0.28^{\mathrm{a}}$ & $1.0 \pm 0.20^{\mathrm{b}}$ \\
\hline Unsaponifiable matter (\% of oil) & $1.5 \pm 0.36^{\mathrm{a}}$ & $1.1 \pm 0.17^{\mathrm{b}}$ \\
\hline Sterols (mg/100 g oil) & $245 \pm 6.22^{\mathrm{a}}$ & $220 \pm 6.10^{\mathrm{b}}$ \\
\hline $\begin{array}{l}\text { Aliphatic and triterpenic alcohols } \\
\text { (mg/100 g oil) }\end{array}$ & $390 \pm 6.15^{\mathrm{a}}$ & $328 \pm 6.49^{b}$ \\
\hline Hydrocarbons (mg/100 g oil) & $92 \pm 3.12^{\mathrm{a}}$ & $150 \pm 4.36^{\mathrm{b}}$ \\
\hline $\mathrm{TH} / \mathrm{TS}^{* *}$ & $0.23 \pm 0.04^{\mathrm{a}}$ & $0.47 \pm 0.04^{\mathrm{a}}$ \\
\hline \multicolumn{3}{|l|}{ Fuel properties } \\
\hline Saponification Value (mg KOH g ${ }^{-1}$ oil) & $180 \pm 3.24^{\mathrm{a}}$ & $186 \pm 3.78^{\mathrm{b}}$ \\
\hline \multicolumn{3}{|l|}{ Iodine value ( $\mathrm{g}$ of $\mathrm{I}_{2} / 100 \mathrm{~g}$ oil) } \\
\hline Determined IV & $168 \pm 1.70^{\mathrm{a}}$ & $160 \pm 1.39^{\mathrm{b}}$ \\
\hline Calculated $^{* * *}$ IV & $170 \pm 1.55^{\mathrm{a}}$ & $161 \pm 1.14^{\mathrm{b}}$ \\
\hline Relative density at $25^{\circ} \mathrm{C} / \mathrm{g} \mathrm{cm}^{-3}$ & $0.938 \pm 0.002^{\mathrm{a}}$ & $0.882 \pm 0.001^{\mathrm{b}}$ \\
\hline \multicolumn{3}{|l|}{$\mathrm{HHV}(\mathrm{MJ} / \mathrm{Kg})$} \\
\hline 2nd Equation & $39.53 \pm 0.62^{\mathrm{a}}$ & $39.41 \pm 0.75^{\mathrm{b}}$ \\
\hline 3rd Equation & $38.56 \pm 0.50^{\mathrm{a}}$ & $40.97 \pm 0.84^{\mathrm{b}}$ \\
\hline 4th Equation & $38.63 \pm 0.66^{\mathrm{a}}$ & $40.66 \pm 0.82^{\mathrm{b}}$ \\
\hline Cetane number & $38.82 \pm 1.18^{\mathrm{a}}$ & $39.64 \pm 1.72^{\mathrm{b}}$ \\
\hline $\begin{array}{l}{ }^{*} \text { Average molecular weight }=\left(3^{\star} 56.1^{*} 100\right. \\
\text { hydrocarbons to total sterols ratio. }{ }^{* *} \mathrm{Calc} \\
(\text { Linoleic acid } \%)+2.616 \text { (Linolenic acid \%). } \\
\pm \text { standard deviation. Means with different } 1 \\
\text { different at }(p \leq 0.05) .\end{array}$ & aponification & $\begin{array}{l}\text { le. }{ }^{*} \mathrm{TH} / \mathrm{TS} \text { total } \\
\text { c acid } \%)+1.732 \\
\text { s of three replicates }\end{array}$ \\
\hline
\end{tabular}

(2006) standard for virgin oils and cold pressed fats and oils, good quality oil should have a peroxide value of less than 10 milliequivalents peroxide $/ \mathrm{kg}$ of oil. The results of peroxide values of flaxseed hull oil after heating agree with Choo et al. (2007) who reported that there were an accumulation of peroxides during heating. The $p-A n V$ of flaxseed hull oil increased with heating. This may be attributed to further decomposition of the less-stable primary oxidative products (hydroperoxides) to form aldehydic compounds. This increased $p$-AnV level was consistent with the PV data presented in Table 2, which confirms that flaxseed hull oil present minor resistance to oxidation under heating conditions. The Oxidation value of flaxseed hull oil sample presented in Table 2 indicates that thermal treatment caused a significant increase of this value. The Oxidation value of heated pumpkin oil (7.13) was lower compared to heated flaxseed hull oil (Vujasinovic et al., 2012). The Theoretical flavor scores $(F)$ values (3.53-6.02) are comparable to flavor score values reported for chickpea (Cicer arietinum L.) (Zia-Ul-Haq et al., 2007). In this table it can be seen that conjugated diene levels at both 234 and $270 \mathrm{~nm}$ increased during heating. These results suggest that reaction of peroxides in heated flaxseed hull oil might have occurred to produce higher amount of secondary oxidation products. Heating process causes a decrease in the oil stability. Flaxseed hull oil obtained for $12 \mathrm{~h}$ at $110^{\circ} \mathrm{C}$ had an oil stability value of $1.0 \mathrm{~h}$. Flaxseed hull oil showed higher oxidation stabilities during heating at $110^{\circ} \mathrm{C}$. Vegetable oils contain a range of components such as tocopherols, phenolics, sterols, etc. which are beneficial to oil stability during heating. The oil stability can be useful to act as a "screening" test and eliminate the possibility of introducing lower stability oils into the production area with all the attendant consequences (Marinova et al., 2012). A gradual decrease of unsaponifiable content was noticed during heating (1.5-1.1\%). This result may be due to the decline of the amount of phytosterols, which are the most abundant compounds of the unsaponifiable fraction of flaxseed hull oil. Sterols, aliphatic and triterpenic alcohols decreased during heating. Under unfavourable conditions (high temperature, presence of air) oxidation products are formed from sterols is observed (Kmiecik et al., 2015). The total amount of hydrocarbons of flaxseed hull oil was positively correlated with the heating temperature. The first recommendation is to use the lowest possible temperature for reaching the desired cooking and technological effects during heating.

The fuel properties tabulated in Table 2 show that as for other liquids, the density of flaxseed hull oil was temperature dependent and decreased in value when temperature increased. Density has been described as one of the most basic or important parameters of fuel as certain performance indicators such as heating value and cetane number are correlated with it (Demirbas, 2000). Compression ignition engines are designed to inject fuel into the combustion chamber by volume rather than mass and it is desirable to maintain diesel density within a tight tolerance to achieve optimal air to fuel ratios. The results show an increase in the saponification value during heating and reached $186 \mathrm{mg} \mathrm{KOH} \mathrm{g}^{-1}$ oil. High saponification value indicates that oils are very useful in production of liquid soap and shampoo industries. Therefore, the value obtained from heated flaxseed hull oil shows that it has high potential for use in the production of liquid soap and shampoos (Gohari Ardabili et al., 2011). The saponification value gives an idea about the number of ester equivalents per unit mass of the oil or biodiesel. The decrease of iodine value (170-160 $\mathrm{g}$ of $\mathrm{I}_{2} / 100 \mathrm{~g}$ oil) (Table 2) correlated well with the decrease of unsaturated fatty acids. Iodine value decrease is indicative of the increased rate of oxidation during heating and could be attributed to oxidation and polymerisation reactions involving the double bonds (Erum et al., 2014). Unsaturation to limited extent is desirable in biodiesel feedstock to meet the requirements for cold weather conditions (Ramos et al., 2009). Unsaturation reduces cloud point, pour point and cold filter plugging point to make biodiesel suitable for cold weather conditions (Ramos et al., 2009). HHV (38.56-40.97) was temperature dependent. Cetane number (CN) (38.82-39.64) of flaxseed hull oil was affected by heating process. Based on these data, heated flaxseed hull oil sample is considered as prospective candidates for feedstock in biodiesel industries according to the biodiesel standards in the USA, Germany and the European Organisations. 


\subsection{Changes in antioxidant compounds contents during flaxseed hull oil heating}

The changes in antioxidant compounds during heating of flaxseed hull oil are shown in Table 3. Heating process caused loss of phenolic acids ( 84 - 60 as gallic acid equivalents $(\mathrm{mg} / 100 \mathrm{~g}$ oil $)$ ) and flavanoids (18-12 as luteolin equivalents $(\mathrm{mg} / 100 \mathrm{~g}$ oil) $)$ contents. The degree of loss of phenolic acids in flaxseed hull oil after heating was less than that of flavanoids. This could confirm that thermal treatment causes an oxidation and polymerization of phenolic compounds. Interest in phenolic compounds is related primarily to their antioxidant activity; nevertheless, they also show important biological activity in vivo and may be beneficial in combating diseases related to excessive oxygen radical formation exceeding the antioxidant defense capacity of the human body (Siger et al., 2008). Heating yielded to a certain degradation of carotenoids. This could be related to the changes of $\beta$-carotene content. Namely, when $\beta$-carotene is heated and exposed to the air, in addition to its degradation, it undergoes polymerization as a dominant side-reaction (Akir et al., 2010). Heating process caused a loss of chlorophyll pigments (3.16-1.84 mg/kg oil). This could confirm that heating process causes a higher degradation of

Table 3. Changes in antioxidant compounds during heating of flaxseed hull oil.

\begin{tabular}{lrr}
\hline \multicolumn{1}{c}{ Antioxidant compounds } & Control & \multicolumn{1}{c}{$\begin{array}{c}\text { Heated } \\
\text { flaxseed hull } \\
\text { oil }\end{array}$} \\
\hline $\begin{array}{l}\text { Total phenolic acids, } \\
\text { as gallic acid equivalents (mg/100 g oil) }\end{array}$ & $84 \pm 9.36^{\mathrm{a}}$ & $60 \pm 6.52^{\mathrm{b}}$ \\
$\begin{array}{l}\text { Total Flavanoids, } \\
\text { as luteolin equivalents (mg/100 g oil) }\end{array}$ & $18 \pm 1.40^{\mathrm{a}}$ & $12 \pm 0.88^{\mathrm{b}}$ \\
Carotenoids (mg/kg oil) & $7.82 \pm 0.64^{\mathrm{a}}$ & $5.25 \pm 0.45^{\mathrm{b}}$ \\
Chlorophyll (mg/kg oil) & $3.16 \pm 0.28^{\mathrm{a}}$ & $1.84 \pm 0.16^{\mathrm{b}}$ \\
PL (\%) & $2.27 \pm 0.32^{\mathrm{a}}$ & $4.18 \pm 0.50^{\mathrm{a}}$ \\
\hline
\end{tabular}

Values given are the means of three replicates \pm standard deviation. Means with different letters (a-c) within a row are significantly different at $(p \leq 0.05)$.



Figure 1. Changes in antioxidant activity during heating of flaxseed hull oil. green pigments that provide coloration to the oil, probably due to an oxidative phenomenon, polymerization of polyphenols or microbial degradation (Arroyo et al., 2009). Table 3 show that phospholipids content increased (2.27-4.18\%) throughout the heating period. Phospholipids are considered to be non-volatile compounds having a higher polarity than triacylglycerols, resulting from thermal, hydrolytic and oxidative alteration (Marinova et al., 2012). The content of phospholipids (PL) in used deep fried fats is an important criterion for assessing the decrease of fat quality (Marinova et al., 2012). In several European countries the maximum value for Total Polar Compounds (TPC) is between 24 and 27\% for commercial frying oils (Marinova et al., 2012).

\subsection{Changes in antioxidant activity during flaxseed hull oil heating}

DPPH assay was the simplest and most accurate method to evaluate the radical scavenging ability of antioxidants (Zou et al., 2015). The absorbance of DPPH from heated oil is shown in Figure 1. Flaxseed hull oil exhibited a higher antioxidant activity. The absorbance of DPPH of heated flaxseed hull oil was $49.74 \%$. Antioxidant activity decreased during heating process. These results show that heated flaxseed hull oil contains less antioxidant compounds which decreased the DPPH radical scavenging capacity. The scavenging action of plant constituents has been found to relate to polyphenolic compounds (Siger et al., 2008). According to Oomah \& Sitter (2009), lignan occurs mainly in the hull of flaxseed. Although the constituents of flaxseed hull oil, which show free radical scavenging action is still unclear, it is possible that the antioxidative activity of flaxseed hull oil is caused, at least, by the presence of polyphenols (Hao \& Beta, 2012). Based on the obtained results, we can conclude that flaxseed hull may play potential roles as health-promoting agents with antioxidant activity in human diets, as well as providing valuable natural antioxidants for the pharmaceutical industry.

\section{Conclusion}

The results of this study show that the heating of flaxseed hull oil during $12 \mathrm{~h}$ caused significant changes in the physicochemical characteristics and antioxidant activity of the resulting oil. The results of the present study proved that saponification value, peroxide value, $p$-anisidine value, oxidation value, specific extinction at 232 and $270 \mathrm{~nm}$ showed significant increases to levels indicating good oil quality indices. The heating process had a negative effect on the oxidative stability of oil, which was observed as a significant decrease in the oil stability (1.4-1.0 h). During the heating process, the most significant changes occurred in the content of phenolic acids, flavonoids, carotenoids followed by total chlorophyll, whereas the changes in the content of phospholipds were the least pronounced. Our study showed that heated flaxseed hull oil marked an antioxidant activity in the DPPH radical-scavenging (49.74\%).

\section{References}

Akir, N., Randrianatoandro, V., Bohuon, P., Laffargue, A., \& Avallone, S. (2010). Kinetic study of $\beta$-carotene and lutein degradation in oils during heat treatment. European Journal of Lipid Science and Technology, 112, 349-361. 
Arroyo, F. N., Bautista, J., Segovia, K. A., García, P., Durán, M. C., Romero, C., Rodríguez, F., \& Garrido, A. (2009). Instability profile of fresh packed seasoned Manzanilla-Aloreña table olives. $L W T$ - Food Science and Technology 42(10), 1629-1639. http://dx.doi. org/10.1016/j.lwt.2009.06.004.

Bligh, E. G., \& Dyer, W. J. (1959). A rapid method of total lipid extraction and purification. Canadian Journal of Biochemistry and Physiology, 37(8), 911-917. http://dx.doi.org/10.1139/o59-099. PMid:13671378.

Bose, P. K. (2009). Empirical approach for predicting the cetane number of biodiesel. International Journal of Automotive Technology, 10(4), 421-429. http://dx.doi.org/10.1007/s12239-009-0048-7.

Choo, W. S., Birch, E. J., \& Dufour, J. P. (2007). Physicochemical and stability characteristics of flaxseed oils during pan-heating. Journal of the American Oil Chemists' Society, 84(8), 735-740. http://dx.doi. org/10.1007/s11746-007-1096-7.

Codex Alimentarius Commission. (2006). Codex Stan 19: edible fats and oils not covered by individual standards. Rome. Retrieved from http://www.codexalimentarius.net/web/standard_list.do?lang=en

Demirbas, A. (1998). Fuel properties and calculation of higher heating values of vegetable oils. Fuel, 77(9-10), 1117-1120. http://dx.doi. org/10.1016/S0016-2361(97)00289-5.

Demirbas, A. (2000). A direct route to the calculation of heating values of liquid fuels by using their density and viscosity measurements. Energy Conversion and Management, 41(15), 1609-1614. http:// dx.doi.org/10.1016/S0196-8904(00)00012-1.

Dieffenbacher, A., \& Pocklington, W. D. (1987). Standard methods for the analysis of oils, fats and derivatives. Oxford: International Union of Pure and Applied Chemistry.

Douce, R. (1964). Identification et dosage de quelques glycérophosphosphatides dans des souches normales et tumorales de scosonères cultivés in vitro. Comptes Rendus de l'Académie des Sciences, 259, 3066-3068.

Erum, Z., Rehana, S., Mehwish, A. H., \& Anjum, Y. (2014). Study of physicochemical properties of edible oil and evaluation of frying oil quality by Fourier Transform-Infrared (FT-IR) Spectroscopy. Arabian Journal of Chemistry. In press.

Fatemi, S. H., \& Hammond, E. G. (1980). Analysis of oleate, linoleate and linolenate hydroperoxides in oxidized ester mixtures. Lipids, 15(5), 379-385. http://dx.doi.org/10.1007/BF02533555.

Folch, J., Lees, M., \& Sloane Stanley, G. H. (1957). A simple method for the isolation and purification of total lipids from animal tissues. The Journal of Biological Chemistry, 226(1), 497-509. PMid:13428781.

Gagnon, N., Côrtes, C., Silva, D., Kazama, R., Benchaar, C., Santos, G., Zeoula, L., \& Petit, H. V. (2009). Ruminal metabolism of flaxseed (Linum usitatissimum) lignans to the mammalian lignan enterolactone and its concentration in ruminal fluid, plasma, urine, and milk of dairy cows. British Journal of Nutrition, 102(7), 1015-1023. http:// dx.doi.org/10.1017/S0007114509344104. PMid:19393113.

Gohari Ardabili, A., Farhoosh, R., \& Haddad Khodaparast, M. H. (2011). Chemical composition and physicochemical properties of pumpkin seeds (Cucurbita pepo Subsp. pepo Var. Styriaka) grown in Iran. Journal of Agricultural Science and Technology, 13, 1053-1063.

Gorinstein, S., Cvikrova, M., Machackova, I., Haruenkit, R., Park, Y. S., Jung, S. T., Yamamoto, K., Leticia Martinez Ayala, A., Katrich, E., \& Trakhtenberg, S. (2004). Characterization of antioxidant compounds in Jaffa sweeties and white grapefruits. Food Chemistry, 84(4), 503-510. http://dx.doi.org/10.1016/S0308-8146(03)00127-4.

Gutfinger, T. (1981). Polyphenols in olive oils. Journal of the American Oil Chemists' Society, 58(11), 966-968. http://dx.doi.org/10.1007/ BF02659771.

Gutierrez, F. (1989). Determination of virgin olive oils stability: comparization between activated oxygen (AOM) and Rancimat methods. Grasas y Aceites, 40, 1-5.
Hao, M., \& Beta, T. (2012). Qualitative and quantitative analysis of the major phenolic compounds as antioxidants in barley and flaxseed hulls using HPLC/MS/MS. Journal of the Science of Food and Agriculture, 92(10), 2062-2068. http://dx.doi.org/10.1002/jsfa.5582. PMid:22278383.

Herchi, W., Al Hujaili, A. D., Sakouhi, F., Sebei, K., Trabelsi, H., Kallel, H., \& Boukhchina, S. (2014). Flaxseed hull: chemical composition and antioxidant activity during development. Journal of Oleo Science, 63(7), 681-689. http://dx.doi.org/10.5650/jos.ess14006. PMid:24919478.

Herchi, W., Bahashwan, S., Sakouhi, F., \& Boukhchina, S. (2015). Influence of harvest year in the physicochemical properties and antioxidant activity of flaxseed hull oils from Tunisia. Food Science and Technology, 35, 175-182.

Kmiecik, D., Korczak, J., Rudzińska, M., Gramza-Michałowska, A., Hęś, M., \& Kobus-Cisowska, J. (2015). Stabilisation of phytosterols by natural and synthetic antioxidants in high temperature conditions. Food Chemistry, 173(15), 966-971. http://dx.doi.org/10.1016/j. foodchem.2014.10.074. PMid:25466113.

Lechvallier, D. (1966). The lipids of Lemnaceae, analysis of fatty acids of lipids of fronds of Spirodela polyrhiza. C. R. Acad. Sci., 263, 1848-1852.

List, G. R., Evans, C. D., Kwolek, W. F., Warner, K., Boundy, B. K., \& Cowan, J. C. (1974). Oxidation and quality of soybean oil: a preliminary study of the anisidine test. Journal of the American Oil Chemists'Society, 51(2), 17-21. http://dx.doi.org/10.1007/BF02545207.

Marinova, E. M., Seizova, K. A., Totseva, I. R., Panayotova, S. S., Marekov, I. N., \& Momchilova, S. M. (2012). Oxidative changes in some vegetable oils during heating at frying temperature. Izvestiia po Himiia, 44(1), 57-63.

Metcalfe, L. D., Schmitz, A. A., \& Pelka, J. R. (1966). Rapid preparation of fatty acids esters from lipids for gas chromatographic analysis. Analytical Chemistry, 38(3), 514-515. http://dx.doi.org/10.1021/ ac60235a044.

Minguez-Mosquera, M. I., Rejano-Navarro, L., Gandulrojas, B., Sanchez Gomez, A. H., \& Garrido-Fernandez, J. (1991). Color-pigment correlation in virgin olive oil. Journal of the American Oil Chemists' Society, 86(5), 332-336. http://dx.doi.org/10.1007/BF02657688.

Oomah, B. D., \& Sitter, L. (2009). Characteristics of flaxseed hull oil. Food Chemistry, 114(2), 623-628. http://dx.doi.org/10.1016/j. foodchem.2008.09.096.

Ramos, M. J., Fernandez, C. M., Casas, A., Rodriguez, L., \& Perez, A. (2009). Influence of fatty acid composition of raw materials on biodiesel properties. Bioresource Technology, 100(1), 261-268. http://dx.doi.org/10.1016/j.biortech.2008.06.039. PMid:18693011.

Siger, A., Nogala-Kalucka, M., \& Lampart-Szczapa, E. (2008). The content and antioxidant activity of phenolic compounds in cold pressed plant oils. Journal of Food Lipids, 15(2), 137-149. http:// dx.doi.org/10.1111/j.1745-4522.2007.00107.x.

Vujasinovic, V., Djilas, S., Dimic, E., Basic, Z., \& Radocaj, O. (2012). The effect of roasting on the chemical composition and oxidative stability of pumpkin oil. European Journal of Lipid Science and Technology, 114(5), 568-574. http://dx.doi.org/10.1002/ejlt.201100158.

Zia-Ul-Haq, M., Ahmad, M., Iqbal, S., Ahmad, S., \& Ali, H. (2007). Characterization and compositional studies of oil from seeds of desi chickpea (Cicer arietinum L.) cultivars grown in Pakistan. Journal of the American Oil Chemists' Society, 84(12), 1143-1148. http:// dx.doi.org/10.1007/s11746-007-1136-3.

Zou, Y., Zhao, Y., \& Hu, W. (2015). Chemical composition and radical scavenging activity of melanin from Auricularia auricula fruiting bodies. Food Science and Technology, 35(2), 253-258. 